\title{
PSYCHOLOGY FOR TEACHERS
}




\section{PSYGHOLOGY FOR TEACHERS}

Third Edition

\section{David Fontana}

Consultant in Educational Psychology

University of Wales College of Cardiff

and Professor, Catedrático

University of Minho, Portugal

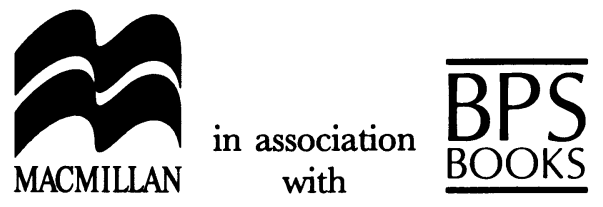


(C) The British Psychological Society 1981

(C) David Fontana 1988, 1995

All rights reserved. No reproduction, copy or transmission of this publication may be made without written permission.

No paragraph of this publication may be reproduced, copied or transmitted save with written permission or in accordance with the provisions of the Copyright, Designs and Patents Act 1988, or under the terms of any licence permitting limited copying issued by the Copyright Licensing Agency, 90 Tottenham Court Road, London W1P 9HE.

Any person who does any unauthorised act in relation to this publication may be liable to criminal prosecution and civil claims for damages.

First edition 1981

Reprinted 1982, 1983, 1985, 1986

Second edition 1988

Reprinted 1989, 1991 (twice), 1993

Third edition 1995

Published by

\section{MACMILLAN PRESS LTD}

Houndmills, Basingstoke, Hampshire RG21 2XS, UK

and London

Companies and representatives

throughout the world

in association with

\section{THE BRITISH PSYGHOLOGIGAL SOGIETY}

St Andrews House, 48 Princess Road East, Leicester LE1 7DR, UK

ISBN 978-0-333-64066-1

ISBN 978-1-349-24139-2 (eBook)

DOI 10.1007/978-1-349-24139-2

A catalogue record for this book is available from the British Library.

$\begin{array}{llllllllll}10 & 9 & 8 & 7 & 6 & 5 & 4 & 3 & 2 & 1\end{array}$

$\begin{array}{llllllllll}04 & 03 & 02 & 01 & 00 & 99 & 98 & 97 & 96 & 95\end{array}$ 


\section{Contents}

Introduction to First Edition xiii

Introduction to Second Edition xvii

Introduction to Third Edition xix

\section{PART I THE EARLY YEARS 1}

\section{Early social development 3}

The child in the home 3

Parental styles 5

$\begin{array}{ll}\text { The influence of attachment upon later development } & 7\end{array}$

The nature of early social learning 9

Gender differences 11

Ethnic groups 14

Social class 17

The family 19

The changing nature of the family $\quad 19$

Family therapy 20

Family conflict 22

The home-school conflict 25

Specific classroom issues $\quad 27$

Language and social development 28

The home and the school 29

SOME QUESTIONS 32

\section{Play 35}

The purpose of play 35

The nature of play 36

Categories of play $\quad 37$

Play and learning $\quad 39$

Play and the curriculum 41

Structuring young children's play 41 
vi Contents

Older children's play $\quad 43$

Sport 43

Computer games 45

SOME QUESTIONS 46

\section{PART II COGNITIVE FAGTORS AND LEARNING}

3 Concept formation and cognitive development

Thinking and education

The work of Piaget 51

Stage 1. Sensori-motor (birth to two years) 53

Stage 2. Pre-operational thought (2-7 years) 54

Stage 3. Concrete operations ( $7-11$ years) 56

Stage 4. Formal operations: 12 years and upwards 57

Criticisms of Piaget 59

Other approaches to cognitive development 61

Information processing 62

Knowledge-acquisition approaches 63

Cognitive development and the classroom 65

The task of the teacher 66

SOME QUESTIONS 69

\section{Language 73}

The beginnings of language $\quad 73$

Encouraging early language $\quad 78$

Language and the school 79

The role of the teacher 80

The rules of language $\quad 81$

The importance of language teaching 81

Types of linguistic competence $\quad 82$

Technical language $\quad 83$

Teacher questions $\quad 83$

Teacher language $\quad 84$

Dialects and accents 86

Enhancing language skills $\quad 86$

The teacher as listener $\quad 87$

Language games $\quad 88$

Reading and writing $\quad 89$

Language and intelligence 90

SOME QUESTIONS 91 


\section{Intelligence 95}

What is intelligence?

95

The measurement of intelligence 95

Intelligence testing $\quad 97$

Models of intelligence $\quad 102$

The measurement of general intelligence $(' g$ ') $\quad 103$

Can IQ be enhanced? 106

Coaching for IQ tests 107

IQ tests and the teacher 107

Improving intelligence $\quad 109$

Intelligence and thinking 110

Is intelligence inherited? 113

Twin studies 115

The approaches of Hebb and Cattell 117

Intelligence and ethnic groups 118

Intelligence and socio-economic factors 120

Gender differences in intelligence 121

SOME QUESTIONS 124

\section{Creativity 127}

What is creativity? 127

Divergent thinking 127

Creativity and intelligence 128

Divergent thinking tests 130

The creative act 131

Creativity and the school

Encouraging divergent thinking 134

Classroom organization and creativity

Creative teaching techniques 136

SOME QUESTIONS 138

\section{Learning 141}

What constitutes learning?

Theories of learning

143

Operant conditioning 143

Instrumental conceptualism

The nature of the learner $\quad 147$

Affective factors 148

Motivation 149

Age, gender and social factors

Memory 152

Study habits 155

The nature of the material to be learned

The cognitive domain $\quad 158$ 
The affective domain $\quad 159$

The psychomotor domain $\quad 160$

Assessment 162

The nature of the learning process 164

Managing the learning process $\quad 170$

Precision teaching 170

The child with learning difficulties 171

Children with low IQ scores 172

Teaching children with low IQ scores 173

Children retarded in achievement $\quad 175$

Helping children retarded in achievement 178

SOME QUESTIONS 180

\section{PART III AFFEGTIVE FAGTORS 185}

8 Personality 187

The origins of personality

The role of parents $\quad 189$

The enduring nature of temperament $\quad 189$

Approaches to personality 190

Ruler or thermometer? 191

Personality traits 191

The work of H.J. Eysenck 192

The work of R.B. Cattell 193

Pros and cons of the trait-based approach 194

Personality traits and learning $\quad 195$

The extraversion-introversion dimension 196

The neuroticism-stability dimension 197

The trait-based approach and individual differences $\quad 198$

Modifying personality traits 199

Personality and academic success 201

Cognitive style 201

Theories of cognitive style $\quad 202$

Cognitive style and learning 206

Personality states 207

Arguments against permanence in personality 208

Telic-paratelic behaviour 208

The state-based approach and counselling 210

The psychodynamic approach 211

Sigmund Freud 211

Personality and motivation $\quad 216$

Motivation and reinforcement 217

Maslow's theory of motivation $\quad 217$ 
Attributional style 220

The teacher's reaction to success and failure in children $\quad 222$

Mood 222

Teachers have moods too 224

Interest 225

Attitudes 227

Attitudes and ego defence 228

Attitudes and behaviour 229

Cognitive dissonance 230

Attitude change 231

SOME QUESTIONS 234

9 Values and moral development

237

What are morals and values? 237

The origins of value systems 238

Kohlberg's six stages of moral development $\quad 239$

Measuring moral development 240

Criticisms of Kohlberg 242

The role of the teacher 243

Some specific moral problems 244

Teaching moral behaviour 246

SOME QUESTIONS 248

10 The self 251

Defining the self 251

What determines the self? 253

The importance of learning in self-concepts 253

Can we know our real self? 254

Carl Rogers' theory of self 255

Conflict between the organism and other people 256

Measuring the self 257

George Kelly and the self 258

Constructs can be changed 262

Self-esteem 262

The development of self-esteem 262

Causal factors in self-esteem 264

Value to the teacher 265

Other influences on self-esteem 266

Encouraging self-esteem 267

Self-esteem is not the same as conceit 268

Assessing self-esteem $\quad 268$

Self-esteem and overassertion/underassertion $\quad 270$

Self-maturity 270

Erikson's eight stages and personal maturity 271 
Children's ages and Erikson's stages 272

Self-maturity and the school 273

Defining the mature personality 274

Self-identity 276

Learning to be adult 276

Understanding the adolescent 277

Role confusion 278

Knowing and being 279

SOME QUESTIONS 281

\section{PART IV SOGIAL INTERACTION, TEAGHER-GHIID RELATIONS AND TEACHER PERSONALITY}

11 Social behaviour and social skills 285

Dyadic interactions 285

Social interaction between teacher and child

Social status 288

Social status and the school 290

Unnecessary assertion of teacher status 291

Social conformity 292

Non-conformity 293

The peer group 296

The school and conformity 296

The lesson as a social encounter $\quad 297$

Teacher awareness of social interaction 298

The five-step episode sequence 299

The nature of communications $\quad 301$

Interaction analysis 301

Social roles 305

Role conflict 306

Social learning and role models $\quad 308$

Copying role models $\quad 309$

Friendship patterns in the classroom $\quad 310$

Classroom subgroups 311

Unsuitable friendships and the friendless child 313

Bullying $\quad 314$

The popular child $\quad 316$

Sociometry 317

Social skills $\quad 318$

Assertiveness $\quad 319$

Assessing and responding to social situations 321

The right atmosphere for social skills training $\quad 322$

Lessons learnt from role playing 323 
The importance of social warmth

The place of self-disclosure 324

SOME QUESTIONS 327

12 Educational guidance and counselling

Counselling in school 331

The problem of confidentiality 332

The importance of sympathy 334

The counselling process 335

Categorizing the child's problem

The role of the counsellor 336

Problems facing the counsellor 339

Social forces and conflicts 340

Vocational guidance $\quad 342$

Developmental stages in career choice

The role of the counsellor in vocational guidance

Sex education $\quad 347$

SOME QUESTIONS 351

13 Class control and management

353

Problem behaviour 353

Defining problem behaviour 354

Behaviour modification techniques 355

The origins of undesirable target behaviours

Indentifying both sides of the problem 358

The eco-behavioural approach $\quad 360$

Objections to behaviour modification techniques

Performance contracts 363

General points on behaviour modification 365

Other aspects of class control and management $\quad 367$

The application of punishment 372

Effective sanctions $\quad 372$

The law of natural consequences

Group behaviour problems 376

Physical confrontation $\quad 377$

School refusal 378

SOME QUESTIONS 380

14 Teacher personality, teacher characteristics, and teacher stress $\quad 383$

Teacher effectiveness $\quad 383$

Assessing teacher characteristics 384

Emotional security in the teacher 386

Teacher attitudes $\quad 387$ 
xii Contents

Teacher styles $\quad 388$

The value of teacher talk $\quad 389$

Introducing variety into teaching methods 390

Teacher stress 391

How to handle stress 394

SOME QUESTIONS 397

Index $\quad 399$ 


\section{Introduction to first edition}

The purpose of this book is to acquaint the reader with those areas of psychology of most practical value to the teacher. It deals, therefore, not only with matters relating directly to the classroom, but with matters pertaining to the child's background outside school and to his or her own self-perceptions and self-concepts. The teacher's task can only be clarified if he or she has a knowledge of children as complete persons rather than simply as individuals who spend the hours from nine o'clock until four sitting in classrooms. The child's personality, ability to learn, motivation, social behaviour, and attitudes towards school are all formed as a consequence of a complex set of interrelated factors which begin at birth (and even before) and extend throughout each moment of waking life. By the time you have finished this book you should have a clear idea of what these factors are, and of how they influence child behaviour. You should also have a clear idea of the part you as teacher can play in the determination of this behaviour, and of how you can best help children to benefit from the learning opportunities that school has to offer.

The application of psychology to education has a long and honoured history, and stretches back to the first occasion when adults tried to influence the behaviour of the young. But it is only in comparatively recent years that the association between the two subjects has been given a firmly scientific basis. By this I mean that it is only during the last 60 years or so that psychology has developed the precision and methodology that allow it to make accurate generalizations about child behaviour, and to provide the teacher with the kind of information necessary if he or she is to make objective professional decisions and judgements. Without such information, the teacher can only fall back upon the sort of anecdotal evidence that we often hear when people are discussing children. We hear, for example, that children are supposed to be basically honest (or dishonest), that they like (or do not like) firm discipline, that they have (or have not) a sense of fair play, that they learn best in informal (or in formal) teaching environments, 
that they are influenced (or not influenced) by what they see on television and so on. One school of thought has it that children's behaviour is the result of conditioning, another that they have the freedom to decide for themselves. We are told on the one hand that abilities such as intelligence are largely inherited, and on the other that they are largely the result of environmental influences. Small wonder that faced with such conflicting statements inexperienced teachers often feel confused, and decide in the end that they must make up their own minds on these and other important matters.

It would be wrong to suggest that modern psychology has final answers to all the questions that face us in education. Children (and teachers) are individuals, and often must be studied as individuals before detailed guidance on particular problems can be given. And, in any case, there are still large gaps in our knowledge that remain to be filled. Human behaviour is very complex and its measurement and assessment fraught with many difficulties. It is in fact this very complexity that gives the study of psychology much of its fascination. But psychology helps teachers recognize the factors that influence child behaviour and learning, and assists them in developing strategies to cope with the tasks that must be faced in the classroom. Furthermore, it helps the teacher to examine his or her own general professional behaviour, and to identify areas where this behaviour may itself have contributed towards particular problems that may have arisen. As is stressed repeatedly throughout the book, psychology shows us that no child's behaviour can be fully understood unless we study also the behaviour of others - teachers, parents, school friends - towards that child. Each individual stands at the centre of a complex matrix of interrelated influences, each of which must be taken into account if we are to comprehend the way in which the individual lives his or her life. In the case of the child this matrix is of particular importance. Still at an early formative stage in development, the child is very much dependent upon other people's behaviour. When the teacher, for example, speaks critically of the child's performance in a particular subject, the child may get the impression that this indicates he or she lacks ability in it, and future performance may deteriorate even further. If we are to help that child improve his or her standards we must look therefore not only at the gaps in their knowledge but at the way in which the teacher, albeit unwittingly, has been undermining the child's confidence in his or her own potential.

Psychology also helps us answer some of the questions on the origins of individual differences. Are we borm different, or do we simply become different as the result of experience? Put another way, are individual differences genetically or environmentally determined? By individual differences we mean not only intelligence but also such things as personality, creativity and motor skills. As we shall see, these answers are of 
critical importance for the teacher since they indicate some of the limits to the influence which education can have upon our lives. If individual differences are largely inherited then there is little that education can do beyond developing what is already there. If, on the other hand, these differences are mainly the result of environment, then education has an enormous potential to redress and alter the consequences of early disadvantage and to help all children achieve the same high standards.

The book deals with children from an early age through into adolescence and the end of compulsory schooling, but this does not mean that you should pick out only those sections that apply to the ages you plan to teach or are actually teaching. For a full understanding of older children the secondary school teacher needs to know something of the formative influences that have been at work during the early part of their lives, while the primary school teacher needs to know something of the problems that may lie ahead of children in their care in order to play a full part in helping them develop the skills and strategies necessary to cope with such problems. The book is designed for both serving teachers and students in training, and the emphasis throughout is upon the practicalities of the teacher's task. Thus theoretical areas of psychology that may be of interest in themselves but that have little real application for what the teacher actually does with children are avoided. A high premium is also placed upon clarity, so that the non-specialist should be able to read the book without experiencing undue difficulties in understanding any of the points raised. Finally, the book can be read as a whole or dipped into, depending upon the needs of the reader. The important thing is that it should be of some use.

\section{The plan of the book}

The plan of the book is simple. In Part I we look at early influences upon the child such as parent-child relationships, family size, and social class. Part II then examines cognitive factors (i.e. mental factors to do with thinking, intelligence and learning) while Part III looks at affective factors (i.e. emotional factors to do with personality, attitudes and values). Part IV looks at social factors: that is, at the factors involved in the child's relationships with the teacher and with the classroom group, and at the teacher him or herself, at what is known about the qualities that make the successful teacher and at the ways in which we study interaction between the teacher and the class.

Each chapter outlines current knowledge in the areas concerned and discusses practical implications for the teacher. At the end of each chapter there are suggestions for further reading, together with a list of 
xvi Introduction to first edition

questions and discussion points. These questions are not designed so much to test your factual knowledge as to draw attention to some of the most important issues discussed in the chapter and to start you thinking creatively about them.

DAVID FONTANA

University College Cardiff, 1981 


\section{Introduction to second edition}

A number of extensive alterations to the material contained in the first edition have been made. Some of this material, in keeping with the policy for the Psychology for Professional Groups series of which this book was a part, was by authors other than myself. These contributions do not appear in the new edition, as I have rewritten the topics covered by them with teacher education exclusively in mind. The convention in the first edition of dividing the theoretical content of each chapter from the practical content has also been changed in the new edition with the result that each chapter now links theory and practice closely together throughout.

Opportunity has also been taken in the new edition to amalgamate the two chapters on personality, since this further helps the linkage of theory and practice. Across a wide area of subjects new sections have also been added, for example on early attachment, ethnic groups, neglected children, the home-school conflict, language and the school, teacher language, approaches to personality, personality states, measuring the self, social status, social roles, social skills and teacher stress. In addition, each part of the book has been thoroughly revised and updated, in the light both of current developments within the field of educational psychology and the feedback to the first edition obtained from students, practitioners and book reviewers. It is the hope of the publishers, the series editors and myself that these extensive alterations will further strengthen the book's usefulness both to student and to serving teachers.

DAVID FONTANA University College Cardiff, 1988 


\section{Introduction to third edition}

There is much new material in this third edition of Psychology for Teachers, as educational psychology is one of the most prolific of all areas of psychological investigation, but it is only included if it meets the test both of academic excellence and of direct relevance to the task of understanding and working with children. Similarly, material from the Second Edition which has been superseded by better work has been omitted, but everything of enduring quality has been retained. The book therefore aims to provide a comprehensive and up-to-the-minute guide to all that is best in the subject of psychology for teachers, and to do so (as in the first two editions) in an interesting, jargon-free, and essentially practical way.

In preparing the third edition, due note has been taken of the feedback, almost invariably helpful and encouraging, received from serving teachers, teacher educators, student teachers and educational psychologists. An extensive survey was also carried out, by the publishers and the author, of all those major teacher education establishments in the UK who use the book, and the observations and comments from colleagues in these establishments have been very gratefully received. It is the wish of the publishers and of the author that the third edition of Psychology for Teachers will continue to serve the needs of all those who use educational psychology, whether as educators, students or as psychologists.

DAVID FONTANA

University of Wales, Cardiff

University of Minho, Portugal, 1995

\section{Recommended general psychology texts}

For readers who wish to extend their reading within the general field of psychology, the following texts are particularly recommended: 
$\mathbf{x} \mathbf{x}$

Atkinson, R.L., Atkinson, R.C., Smith, E.E. and Bem, D.J. (1993) Introduction to Psychology (11th edn). Fort Worth, Philadelphia: Harcourt Brace Jovanovich.

Hayes, N. (1994) Foundations of Psychology. London and New York: Routledge.

Ornstein, R. and Carstensen, L. (1991) Psychology: The Study of Human Experience. Fort Worth, Philadelphia: Harcourt Brace Jovanovich. 